\title{
Athlete self-efficacy scale: Development and psychometric properties
}

\author{
Çalık Veli Koçak \\ Faculty of Sport Science, Hitit University Kuzey Kampüsü, Çorum, Turkey
}

abstract

Background: It is important that psychological structures have an impact on athlete performance, such as selfefficacy can be measured consistently. The aim of this study is to develop a measurement tool with psychometric properties that can measure the self-efficacy beliefs of athletes.

Material and methods: The participants of the study consisted of 325 athletes (age $21.6 \pm 4.2$ ) who actively pursue sports in various sports branches in Turkey. In the validity and reliability analysis of the scale, exploratory and confirmatory factor analyzes were used. Cronbach's Alpha reliability coefficient value of the total scale is .88 .

Results: The validity and reliability analysis results of the scale revealed that the scale was generally in perfect fit. As a result, it can be said that the Athlete Self Efficacy Scale (ASES) is a valid and reliable measurement tool and can be used to determine the self-efficacy levels of adult athletes.

Conclusions: Validity and reliability studies of the Athlete Self Efficacy Scale should be repeated specific to the sport branch or in younger age groups. In addition, athlete's self-efficacy is a universal concept. In this respect, it is valid in other cultures and it is recommended to adapt the scale to other languages and cultures.

Key words: sports, athlete, self-efficacy, validity, reliability, scale development.

\section{article details}

Article statistics: Word count: 4,540; Tables: 7; Figures: 2; References: 37

Received: May 2020; Accepted: December 2020; Published: December 2020

Full-text PDF: http://www.balticsportscience.com

Copyright @ Gdansk University of Physical Education and Sport, Poland

Indexation: Celdes, Clarivate Analytics Emerging Sources Citation Index (ESCl), CNKI Scholar (China National Knowledge Infrastructure), CNPIEC, De Gruyter - IBR (International Bibliography of Reviews of Scholarly Literature in the Humanities and Social Sciences), De Gruyter - IBZ (International Bibliography of Periodical Literature in the Humanities and Social Sciences), DOAJ, EBSCO - Central \& Eastern European Academic Source, EBSCO - SPORTDiscus, EBSCO Discovery Service, Google Scholar, Index Copernicus, J-Gate, Naviga (Softweco, Primo Central (ExLibris), ProQuest - Family Health, ProQuest - Health \& Medical Complete, ProQuest - Illustrata: Health Sciences, ProQuest - Nursing \& Allied Health Source, Summon (Serials Solutions/ProQuest, TDOne (TDNet), Ulrich's Periodicals Directory/ulrichsweb, WorldCat (OCLC)

Funding: This research received no specific grant from any funding agency in the public, commercial, or not-for-profit sectors.

Conflict of interests: Corresponding author: Author has declared that no competing interest exists.

Dr. Çalık Veli Koçak, Hitit University Kuzey Kampüsü, Çorum 19030, Turkey; e-mail: kocakveli@hotmail.com; velikocak@hitit.edu.tr

Open Access License: This is an open access article distributed under the terms of the Creative Commons Attribution-Non-Commercial-NoDerivatives 4.0 International (https://creativecommons.org/licenses/by-nc-nd/4.0/), which permits use, distribution and reproduction in any medium, provided the original work is properly cited, the use is non-commercial and is otherwise in compliance with the license. 


\section{INTRODUCTION}

The importance of high level physical skills and capacity is essential for success and high performance in sports. Athletes must increase their physical and technical skills to achieve success because athletic performance is focused on success in sports. Psychological factors are among the most important basic components of high performance and success in sports. Therefore, it can be said that psychological factors are very important in addition to physical and physiological factors on the way to success in every sport discipline.

Studies that demonstrate the effect of psychological factors on performance in sports [1-3] are quite numerous. Goals, performance and success in sports are affected by psychological factors, such as perception, attitude, expectation, anxiety, stress, motivation, self-confidence, self-efficacy. One of the important concepts is the self-efficacy belief. Self-efficacy has been evaluated concerning field, task or general self-efficacy, and extensive research has been done on these issues. At the same time, it is seen that the subject of self-efficacy in sports and athletes is also investigated in different relational situations. The concept of athlete self-efficacy, which constitutes the content of this research, is based on Bandura's Self-Efficacy Theory.

\section{SELF-EFFICACY}

Self-efficacy as a psychological concept is a person's belief in performing a task, and it can affect the level of activity, efforts, determination and success in the task [4]. People have various levels of self-efficacy coming from individual and indirect experiences, personal qualities and social support. People set goals according to their self-efficacy levels. When working on tasks, they learn about how well they perform. This information affects their self-efficacy for continuous learning and performance. The information which is collected through experiences is evaluated cognitively, and the self-efficacy level increases or decreases [5].

Self-efficacy is classified as task specific, domain specific and general self-efficacy. According to Bandura [5], self-efficacy beliefs towards the field or task directly affect the behavior. In fact, the more customized to a certain field the self-efficacy beliefs are, the more successful the behavioral results in that domain can be. On the other hand, general self-efficacy is the state of psychological well-being of an individual and supports the task and the field self-efficacy [6]. Sport has a unique structure that includes performing various tasks. Accordingly, the concept of athlete self-efficacy should be examined in order to explain the success and performance outcomes in the field of sports.

\section{SELF-EFFICACY IN ATHLETES}

Bandura [5] proposed the theory of self-efficacy as a cognitive explanation tool for differences in the abilities and achievements of people, teams and organization leaders, including athletic tasks in the field of sports. According to Bandura [5], self-efficacy beliefs are the main determinants of the motivation levels of people in order to reach a certain goal. Feltz and Weiss [7] introduced the concept of self-efficacy in sports in this direction and stated that self-efficacy is one of the most effective psychological structures that mediate success in sport.

Many different components have an impact on the athlete's performance. One of these is self-efficacy belief. According to Feltz et al. [8], self-efficacy in sports involves a more complex structure than beliefs about performing different situational tasks and motor skills, such as hitting the ball hard or curved, or hitting the opponent's court. Self-efficacy in sports is a combination of beliefs about ameliorative efficacy, collective efficacy, competitive efficacy, coping efficacy, learning efficacy, performance 
efficacy, preparatory efficacy, self-regulation efficacy and motor skills efficacy. Self-efficacy in sports with these features it is a strong determinant in achieving target setting, sportive learning, and individual and collective performance [9]. Based on this information, it can be predicted that athlete's self-efficacy includes general and special duties in the field of sports. Considering the evaluations made, athlete's self-efficacy can be defined as the belief in individual abilities to successfully perform different performance tasks related to sport.

Self-efficacy beliefs in sports affect the success level of the target behavior. Thus, athletes set targets according to their self-efficacy and determine the road maps they will follow. When they fall below their targets, they evaluate the performances with dissatisfaction. Whether this dissatisfaction is an incentive or deterrent to further efforts is also influenced to a certain extent by the athlete's self-efficacy and degree of inconsistency in achieving the goal [8]. People with high self-efficacy beliefs increase their level of effort and determination in the face of negative discrepancies between their personal goals and achievements, while those who doubt themselves give up quickly [5].

Bandura [10] points out that human behavior is based on what is believed to be correct. However, people often evaluate their level of self-efficacy incorrectly and may have higher or lesser judgment about their level of self-efficacy.

This situation directly affects the behavior of individuals and their expectations resulting from these behaviors. Thus, while deciding on the behavior, a person can make important mistakes that affect the outcome expectation by acting timidly or over-eagerly [11].

The relationship between self-efficacy belief and success and performance suggests that such a relationship may also be a possible state for athletes, especially that athletes with high athlete self-efficacy beliefs can set more realistic goals regarding their a thletic tasks. Athletes with high self-efficacy can do more to succeed, be more resilient, maintain their motivation better and manage stress effectively. At the same time, they can reach their success targets more easily by showing high performance with the contribution of their talents. On the other hand, athletes with low self-efficacy beliefs can display an insecure attitude even in the tasks they can accomplish and in the face of the problems they can overcome. These athletes can succumb to stress and depression in a shorter time. In addition, failure can decrease the perception of efficacy of athletes with low efficacy belief. This may cause the athlete to fail in other areas as well. Moreover, it may cause athletes to exhibit behaviors that can go from sports to rupture by reducing their coping power.

Self-efficacy beliefs that affect human life can be determined even at an early age with appropriate measurement tools and methods. In this way, a good understanding can be provided for the person to be successful in line with his/her abilities [12]. The person's selfefficacy perception and belief should be measured in various environmental conditions, in various domains and related skills [13]. The measurement tools to be developed must have the power to estimate and provide a valid measurement. For this, it is absolutely necessary to define the task, ability or situation $[13,14]$.

From this point of view determining the level of self-efficacy belief in line with the athlete's tasks is very important in terms of evaluating their abilities and performances more accurately. The athlete who can evaluate himself/herself correctly, will be able to determine his/her positive and negative characteristics more easily in line with his/her goal orientations and can use his/her abilities. At the same time he/she will be able to manage his/her perception of success and failure and evaluate performance more accurately. 
Literature analysis shows that the self-efficacy scales in the field of sports mostly include such scales as participation in exercise [15, 16], rock climbing self-efficacy [17, 18], coaching self-efficacy $[19,11]$ and referee self-efficacy [20]. However, there is no measurement tool that focuses on the self-efficacy of athletes' duties and has the power to measure the multi-dimensional structure of athlete's self-efficacy. Therefore, the athlete self-efficacy scale is necessary with psychometric properties that could explain the beliefs of athlete's self-efficacy.

The aim of this research is to develop a measurement tool with psychometric properties that can measure athletes' self-efficacy belief levels. This research is important in terms of the development of a scale that has not been exemplary in the literature.

\section{MATERIAL AND METHODS}

This research is a methodological study that aimed at developing a scale that can measure the self-efficacy beliefs of athletes about their athletic capacities. Accordingly, the research has been designed with the creation of an item pool, presentation to the expert opinion, pre-experiment, validity and reliability analysis stages. The process steps of the research are shown in Figure 1.

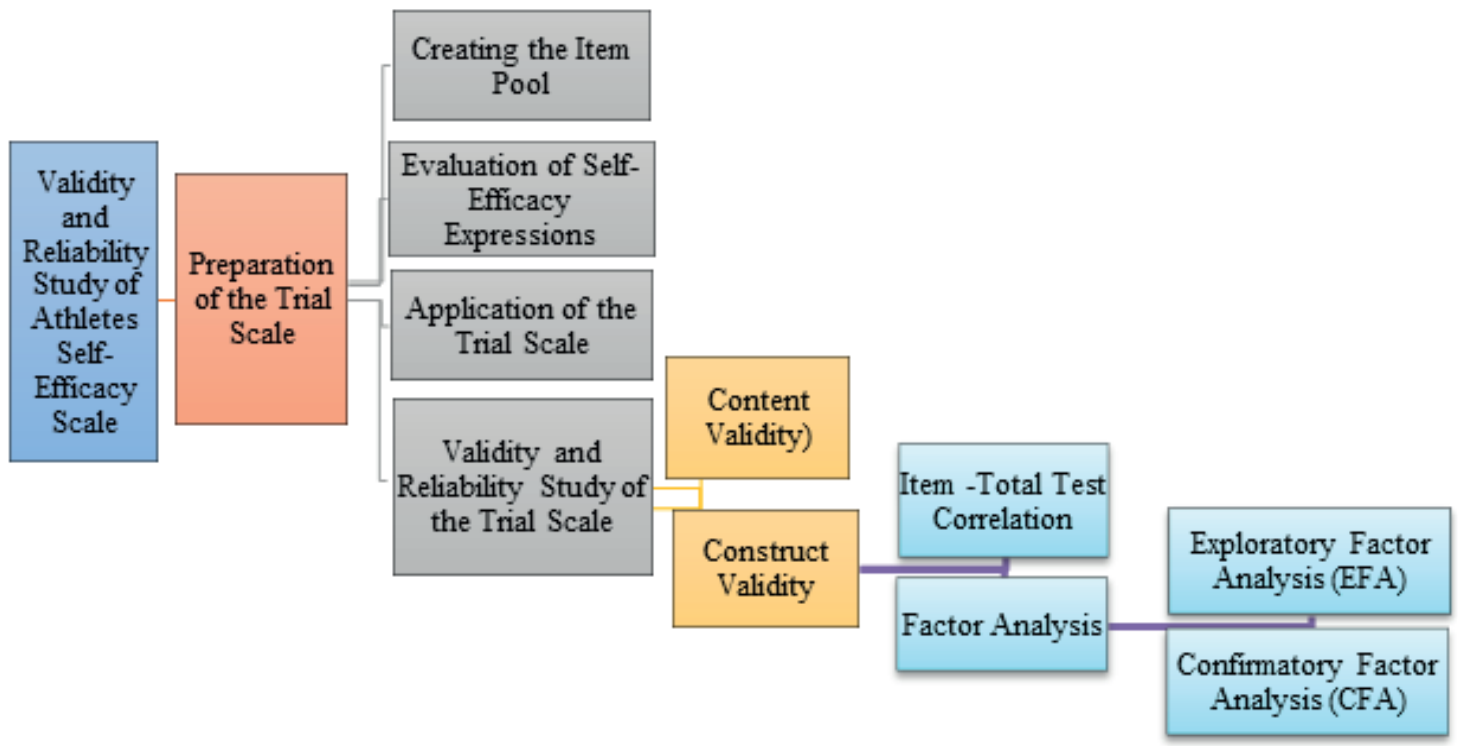

Fig. 1. Flow chart of the research

\section{Participants}

The sample of the study consisted of 325 senior athletes who continue their active sports life in various sport disciplines (badminton, basketball, football, futsal, wrestling, handball, judo, table tennis, volleyball, tennis, track and field and taekwondo). In the scale development studies, a sample size of 300+ was reported to be sufficient [21]. The athletes were selected using the convenience sampling method [22]. Demographic information of the sample group of the research is given in Table 1 . 
Table 1. Demographic information of the sample group

\begin{tabular}{|c|c|c|c|}
\hline Demographic information & Groups & $f$ & $\%$ \\
\hline \multirow{2}{*}{ Gender } & Female & 99 & 30.5 \\
\hline & Male & 226 & 69.5 \\
\hline \multirow{4}{*}{ Age } & 18-19 age & 122 & 37.5 \\
\hline & $20-21$ age & 95 & 29.2 \\
\hline & $22-23$ age & 49 & 15.1 \\
\hline & $24+$ age & 59 & 18.2 \\
\hline \multirow{2}{*}{ Type of sport discipline } & Individual sport disciplines & 115 & 35.4 \\
\hline & Team sport disciplines & 210 & 64.6 \\
\hline \multirow{4}{*}{$\begin{array}{l}\text { Athletic experience } \\
\text { (duration in year) }\end{array}$} & $8-9$ years & 78 & 24.0 \\
\hline & 10-11 years & 76 & 23.4 \\
\hline & $12-13$ years & 125 & 38.5 \\
\hline & 14 years & 46 & 14.2 \\
\hline \multirow{2}{*}{ National athlete status } & Yes & 97 & 29.8 \\
\hline & & 228 & 70.2 \\
\hline
\end{tabular}

\section{Data COllection and data COLlection tOOLS}

The data of the research were collected by Personal Information Form and Athlete Self-Efficacy Scale Trial Form.

Personal Information Form: Questions about the gender, age, type of sport discipline, athletic experience duration and national athletic status of the athletes were included.

Athlete Self-Efficacy Scale Trial For m: In this section there are expressions regarding the professional self-efficacy of athletes. The preliminary application scale emerged as a 5-point Likert type self-assessment scale with 17 items.

The data of the research were obtained in the 2019-2020 competition season by means of data collection forms created electronically. "The Ethics Committee for Non-Interventional Research" approval was obtained from the Ethics Committee of Hitit University. "Informed Consent Form" was used to inform the participants about the research and to inform them about their rights. This form has been added to the data collection tool for approval by the researcher and the participant.

\section{STATISTICAL ANALYSIS}

Item-Total Test Correlation, Kaiser-Meyer-Olkin (KMO) Coefficient and Bartlett's Sphericity Test, Exploratory Factor Analysis (EFA) were performed in the validity and reliability analysis of the Athlete's Self-Efficacy Scale. Confirmatory Factor Analysis (CFA) and finally Cronbach's alpha coefficient were used to provide evidence of the factor structure obtained after EFA. SPSS 21 and Lisrel 8.80 statistics programs were used to analyze the data.

\section{RESULTS}

In this section, firstly, the applications made in the steps of the research, and then the findings related to the validity and reliability analysis are included. Validity refers to the extent to which scales could accurately measure the property to be measured [23], and reliability refers to the scale's ability to produce repeatable results [24]. 


\section{TRIAL SCALE VALIDITY ANALYSIS AND FINDINGS}

\section{Content validity}

In order to create an item pool at the beginning of the development process steps of the scale, athletes' self-efficacy scales in the literature have been researched, but the scales directly related to the subject have not been reached. Therefore, other self-efficacy scales in the field of sports were examined, and attempt was made to draw up the conceptual framework. In addition, a focus group study was conducted with 4 athletes (team athlete $\mathrm{n}=2$, individual athlete $\mathrm{n}=2$ ) in order to write statements that can explain the athlete's self-efficacy. These athletes were high level competitors in their sport disciplines. In the focus group study, the concept and characteristics of self-efficacy were explained to the participants. Then the participants reported what the athlete's self-efficacy might be and under which titles they could be grouped. At the end of the focus group study and review of the literature, a pool of 30 items on athlete's self-efficacy was created.

In the next step, expert opinion was obtained to determine the suitability of the selfefficacy statements for the purpose and the characteristic to represent the field to be measured. 5 researchers conducting research on self-efficacy were a sked to evaluate a total of 30 items in the item pool. Researchers evaluated the scale items between 1 point (not suitable), 2 points (somewhat suitable), 3 points (very suitable) and 4 points (completely suitable). Then they suggested their opinions about the items, and they offered new item that can explain the self-efficacy of an athlete. In this way, the "Content Validity Index" [25] was determined by dividing the number of experts indicating the "completely suitable" view on the items by the total number of experts. After the expert opinion, 15 items that were not suitable in terms of scope and language were removed from the trial scale, and then, with the addition of 2 items suggested by the experts, a 17-item trial scale form was created. The formula $(n-1(n-1) / n=(5-1) / 5=0.80)$ was used to calculate the scale score ranges. Likert rating of the pre-application form of the scale was formed as follows: "I Do Not Agree" - 1 point (1.00-1.79)", "I Agree Less" - 2 points (1.80-2.59), "I agree moderately" - 3 points (2.60-3.39), "I agree very much" - 4 points (3.40-4.19) and "I completely agree" - 5 points $(4.20-5.00)$.

\section{CONSTRUCT VALIDITY}

Item total test correlation

In order to determine the construct validity of 17 items in the trial scale, the item total test correlation coefficient of each item was calculated.

Table 2. Trial scale item-total test correlation coefficients

\begin{tabular}{|c|c|c|c|c|c|c|c|c|}
\hline Items & $\begin{array}{l}\text { Item total } \\
\text { correlation } \\
\text { coefficient }\end{array}$ & $\begin{array}{c}\text { Cronbach's } \\
\text { alpha } \\
\text { if item } \\
\text { deleted }\end{array}$ & Items & $\begin{array}{l}\text { Item total } \\
\text { correlation } \\
\text { coefficient }\end{array}$ & $\begin{array}{c}\text { Cronbach's } \\
\text { alpha } \\
\text { if item } \\
\text { deleted }\end{array}$ & Items & $\begin{array}{l}\text { Item total } \\
\text { correlation } \\
\text { coefficient }\end{array}$ & $\begin{array}{c}\text { Cronbach's } \\
\text { alpha } \\
\text { if item } \\
\text { deleted }\end{array}$ \\
\hline & $r$ & $\alpha$ & & $r$ & $\alpha$ & & $r$ & $\alpha$ \\
\hline 1 & .596 & .894 & 7 & .586 & .894 & 13 & .478 & .898 \\
\hline 3 & .633 & .892 & 9 & .630 & .893 & 15 & .449 & .898 \\
\hline 4 & .653 & .892 & 10 & .548 & .895 & 16 & .535 & .896 \\
\hline 5 & .565 & .895 & 11 & .511 & .897 & 17 & .641 & .892 \\
\hline 6 & .500 & .897 & 12 & .538 & .895 & & & \\
\hline
\end{tabular}


When calculating the item-total test correlation coefficients of the Athlete Self-Efficacy Scale trial form, the lower cut-off point was taken as .40. As seen in Table 2, there is a statistically significant difference between the correlation coefficients of the items $(r=.449-.653)(p<0.05)$. As a result of this analysis, it was seen that the total test correlation coefficient of any item was not less than 0.40 . Therefore, none of the items were removed from the trial scale.

\section{FACTOR ANALYSIS}

Exploratory Factor Analysis (EFA) was performed to determine the possible dimensions of the scale to be developed and to evaluate the reliability of the scale items and dimensions. Confirmatory Factor Analysis (CFA) was performed to confirm the item-factor fit that appeared in exploratory factor analysis.

Exploratory Factor Analysis (EFA): The suitability of the trial scale for factor analysis was analyzed with KMO coefficient and Bartlett's Sphericity Test. Büyüköztürk [21] stated that the KMO should be higher than .60 and the calculated Chi-square value of the Bartlett's Test should be statistically significant for the suitability of the data for factor analysis.

Table 3. KMO vs Bartlett's Test findings

\begin{tabular}{ccc} 
Kaiser-Meyer-Olkin Measure of Sampling Adequacy. & & .874 \\
\hline & Chi-Square & 2417.840 \\
Bartlett's Test of Sphericity & $\mathrm{df}$ & 136 \\
& $\mathrm{p}$ & .000 \\
\hline
\end{tabular}

The sampling adequacy coefficient (KMO) of this research was .874, a nd Bartlett's Test $\chi^{2}$ value was determined as $2417.84(\mathrm{p}<.001)$ (Table.3). KMO and Bartlett's Test results show that the sample size is sufficient and suitable for factor analysis.

Table 4. Trial scale factor eigenvalues and variance explanation rates

\begin{tabular}{cccc} 
Factor & Initial eigenvalues & \% of variance & Cumulative \% \\
\hline 1 & 6.657 & 39.161 & 39.161 \\
2 & 1.405 & 8.263 & 47.423 \\
3 & 1.275 & 7.501 & 54.924 \\
4 & 1.012 & 5.950 & 60.874 \\
\hline
\end{tabular}

Exploratory Factor Analysis proposed 4 factors with eigenvalue greater than 1 and explained total variance by $60.874 \%$. According to the result of the exploratory factor analysis of the trial scale, the factor structures and the items are shown in Table 5.

Table 5. Trial scale items and factors after Exploratory Factor Analysis

\begin{tabular}{|c|c|c|c|c|c|c|}
\hline \multirow{2}{*}{$\begin{array}{l}\text { Item } \\
\text { number }\end{array}$} & \multirow{2}{*}{ Factor names } & \multirow{2}{*}{ Items } & \multicolumn{4}{|c|}{ Factor } \\
\hline & & & 1 & 2 & 3 & 4 \\
\hline 10 & \multirow{4}{*}{$\begin{array}{l}\text { Professional } \\
\text { thought } \\
\text { efficacy }\end{array}$} & I work devotedly to achieve my performance goals. & .823 & & & \\
\hline 12 & & $\begin{array}{l}\text { In order to protect my performance, I train } \\
\text { individually in and out of season. }\end{array}$ & .640 & & & \\
\hline 9 & & I take care to protect my health. & .625 & & & \\
\hline 11 & & $\begin{array}{l}\text { I organize my life so that it does not affect my } \\
\text { performance negatively. }\end{array}$ & .609 & & & \\
\hline
\end{tabular}




\begin{tabular}{|c|c|c|c|c|c|c|}
\hline \multirow{2}{*}{$\begin{array}{l}\text { Item } \\
\text { number }\end{array}$} & \multirow{2}{*}{ Factor names } & \multirow{2}{*}{ Items } & \multicolumn{4}{|c|}{ Factor } \\
\hline & & & 1 & 2 & 3 & 4 \\
\hline 14 & \multirow{5}{*}{$\begin{array}{l}\text { Personality } \\
\text { efficacy }\end{array}$} & $\begin{array}{l}\text { I effectively cooperate and work in cohesion with my } \\
\text { stakeholders in the field of sports. }\end{array}$ & & .777 & & \\
\hline 16 & & I have high self-confidence. & & .759 & & \\
\hline 15 & & I act in accordance with fair play. & & .685 & & \\
\hline 17 & & I take responsibility during the competition. & & .481 & & \\
\hline 13 & & $\begin{array}{l}\text { I receive education for my personal development in } \\
\text { every field. }\end{array}$ & & .450 & & \\
\hline 2 & \multirow{4}{*}{$\begin{array}{c}\text { Sport } \\
\text { discipline } \\
\text { efficacy }\end{array}$} & $\begin{array}{l}\text { I have the motor skills required for my sport } \\
\text { discipline. }\end{array}$ & & & -.931 & \\
\hline 1 & & $\begin{array}{l}\text { I have the physical fitness required for my sport } \\
\text { discipline }\end{array}$ & & & -.864 & \\
\hline 3 & & $\begin{array}{l}\text { I have the technical skills required for my sport } \\
\text { discipline. }\end{array}$ & & & -.640 & \\
\hline 4 & & $\begin{array}{l}\text { I successfully apply the individual and team tactics } \\
\text { during the competition. }\end{array}$ & & & -.511 & \\
\hline 6 & \multirow{4}{*}{ Psychological } & I help my teammates to be their motivate. & & & & -.787 \\
\hline 7 & & efficacy & & & & -.642 \\
\hline 5 & & I motivate myself. & & & & -.591 \\
\hline 8 & & I control my emotions. & & & & -.513 \\
\hline
\end{tabular}

Factor load values of 4 items in the first factor between .609 and .823 , factor load values of 5 items in the second factor between .450 and .777, factor load values of the 4 items in the third factor between -.511 and -.931, and factor load of the 4 items in the fourth factor values appear to vary between -.513 and -.787.

Confirmatory Factor Analysis (CFA): At this stage of the study, Confirmatory Factor Analysis (CFA) was performed for the model consisting of 4 hidden variables (professional thought efficacy, personality efficacy, sport discipline efficacy, and psychological efficacy) and 17 observable variables (scale items).

Considering the modification indices suggested in the confirmatory factor analysis, the 13 th item in the trial scale was removed from the scale. In addition, 16-item 4-dimensional model was confirmed by applying modifications between the 1st and the 2nd items, the 14th and the 15th items, which are within the same factor (Table 6, Figure 2). Standardized Error Variances, $t$ value and $\mathrm{R}^{2}$ values for the scale items are shown in Table 6 after the 13th item was removed in CFA.

Table 6. Trial scale items after Confirmatory Factor Analysis

\begin{tabular}{cccc|cccc}
\hline Items & $\begin{array}{c}\text { Standardized error } \\
\text { variances }\end{array}$ & $\mathrm{t}$ & $\mathrm{R} 2$ & Items & $\begin{array}{c}\text { Standardized error } \\
\text { variances }\end{array}$ & $\mathrm{t}$ & $\mathrm{R}^{2}$ \\
\hline 1 & 0.60 & 10.25 & 0.61 & 9 & 0.45 & 14.30 & 0.74 \\
2 & 0.62 & 11.54 & 0.62 & 10 & 0.55 & 12.50 & 0.67 \\
3 & 0.34 & 16.95 & 0.81 & 11 & 0.63 & 10.98 & 0.61 \\
4 & 0.32 & 11.37 & 0.82 & 12 & 0.58 & 11.99 & 0.65 \\
5 & 0.59 & 11.79 & 0.64 & 14 & 0.69 & 9.75 & 0.55 \\
6 & 0.60 & 11.66 & 0.63 & 15 & 0.73 & 9.05 & 0.52 \\
7 & 0.52 & 13.10 & 0.69 & 16 & 0.48 & 1348 & 0.72 \\
8 & 0.51 & 13.41 & 0.70 & 17 & 0.38 & 15.25 & 0.79 \\
\hline
\end{tabular}

After the 13th item in the trial scale has been removed and the modifications between the items have been made, the factor-item connection diagram for CFA is given in Figure 2 . 


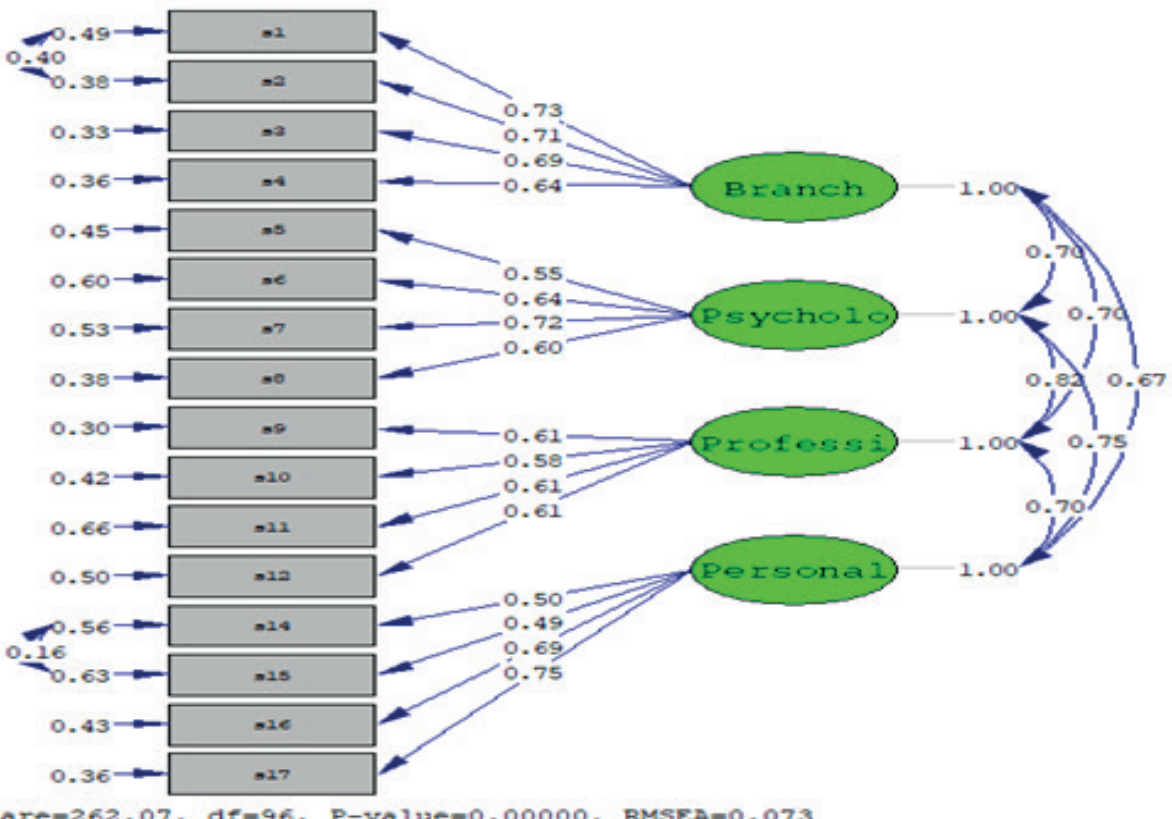

Figure 2. CFA, Factor-Item Relationship

Table 7. The CFA fit indices values of the trial scale

\begin{tabular}{ccccc}
\hline Fit indices & Scale indices values & Perfect fit criteria & Good fit criteria & Result \\
\hline$\chi^{2} / \mathrm{df}$ & $262.05 / 96=2.72$ & $<2$ & $<3$ & Good fit \\
$\mathrm{NFI}$ & 0.95 & $>0.95$ & $>0.90$ & Perfect fit \\
$\mathrm{NNFI}$ & 0.96 & $>0.95$ & $>0.90$ & Perfect fit \\
$\mathrm{CFI}$ & 0.97 & $>0.95$ & $>0.90$ & Perfect fit \\
$\mathrm{IFI}$ & 0.97 & $>0.95$ & $>0.90$ & Perfect fit \\
$\mathrm{RFI}$ & 0.97 & $>0.95$ & $>0.90$ & Perfect fit \\
$\mathrm{AGFI}$ & 0.87 & $>0.95$ & $>0.85$ & Good fit \\
$\mathrm{GFI}$ & 0.91 & $>0.95$ & $>0.90$ & Good fit \\
RMSEA & 0.073 & $<0.05$ & $<0.08$ & Good fit \\
RMR & 0.054 & $<0.05$ & $<0.08$ & Good fit
\end{tabular}

CFA calculated the critical $n$ value as 156.41 for this research. This finding reveals that the sample size of 325 people in the study is sufficient. When the fit indexes of the scale are evaluated, $\chi^{2} / \mathrm{df}(2.72<3)$ good fit, NFI $(0.95 \geq 0.95)$ perfect fit, NNFI $(0.96>0.95)$ perfect fit, CFI $(0.97>0.95)$, IFI $(0.97>0.95)$, RFI $(0.97>0.95)$ indices were found to perfect fit. However, AGFI (0.87 > 0.85), GFI $(0.91>0.90)$, RMSEA $(0.073<0.08)$, RMR $(0.054<0.08)$ indices were found to be good fit.

\section{RELIABILITY ANALYSIS OF THE TRIAL SCALE}

The ability of a measurement tool to provide consistent and stable measurement results in different measurements is explained as reliability [27]. Cronbach's Alpha Reliability Coefficient was used to determine the reliability of the scale. Correlation coefficients of the factors with each other and the total scale were also analyzed with Spearman Brown Correlation Test. Internal consistency coefficients and correlation values for the Athlete Self-Efficacy Scale and its factors are shown in Table 8. 
Table 8. Internal consistency coefficients and correlation values for the total and factors of the scale

\begin{tabular}{cccccccc} 
Dimensions & $\mathrm{n}$ & $\mathrm{Cr} \mu$ & $\begin{array}{c}\text { Sport } \\
\text { discipline } \\
\text { efficacy }\end{array}$ & $\begin{array}{c}\text { Psychological } \\
\text { efficacy }\end{array}$ & $\begin{array}{c}\text { Professional } \\
\text { thought } \\
\text { efficacy }\end{array}$ & $\begin{array}{c}\text { Personality } \\
\text { efficacy }\end{array}$ & Scale total \\
\hline $\begin{array}{c}\text { Sport discipline } \\
\text { efficacy }\end{array}$ & 325 & .841 & 1.000 & $.550^{* *}$ & $.534^{* *}$ & $.501^{* *}$ & $.795^{* *}$ \\
$\begin{array}{c}\text { Psychological } \\
\text { efficacy }\end{array}$ & 325 & .756 & $.550^{* *}$ & 1.000 & $.582^{* *}$ & $.545^{* *}$ & $.832^{* *}$ \\
$\begin{array}{c}\text { Professional } \\
\text { thought efficacy }\end{array}$ & 325 & .752 & $.534^{* *}$ & $.582^{* *}$ & 1.000 & $.490^{* *}$ & $.791^{* *}$ \\
$\begin{array}{c}\text { Personality } \\
\text { efficacy }\end{array}$ & 325 & .760 & $.501^{* *}$ & $.545^{* *}$ & $.490^{* *}$ & 1.000 & $.781^{* *}$ \\
$\begin{array}{c}\text { Scale total } \\
\text { Scat }\end{array}$ & 325 & .898 & $.795^{* *}$ & $.832^{* *}$ & $.791^{* *}$ & $.781^{* *}$ & 1.000 \\
\hline
\end{tabular}

Cronbach's Alpha ( $\mathrm{Cr} \mu)$ internal consistency coefficients of the whole scale and subdimensions are above .70. It was determined that the scale sub-dimensions correlated positively with each other and the scale as a total.

\section{DISCUSSION}

In the scale development studies, the lower breakpoint may be .30 and above in the item total test correlation coefficient calculations [26]. In order to determine the construct validity of the trial scale, the sub-break point was taken as .40 to calculate the coefficients in the total test correlation analysis. The coefficients of all items in the trial scale are above .40 (Table 2). This result revealed that the trial scale is consistent with the literature.

Before conducting Exploratory Factor Analysis, Sampling Adequacy coefficient of the test scale was examined. It was determined that the KMO coefficient (.874) was above the recommended value of .60 and the result of the Bartlett's Sphericity Test was statistically significant $(2417.84=\mathrm{p}<.001)$ (Table 3$)$. These results showed that the sample size of the trial scale is suitable for factor analysis in this aspect.

At the end of the Exploratory Factor Analysis, 4 factor structures with eigenvalues greater than 1 emerged. The total variance rate explained by the four factors is $60.874 \%$ (Table 4). It is stated in the literature that variance explanation rates between $40 \%$ and $60 \%$ are sufficient [28]. These results revealed that the contribution of the defined factors to the total variance is sufficient and shows consistency with the literature.

While creating the factor pattern in scale development studies, factor loads above 0.30 can be taken into consideration as the lower breakpoint [26]. In this study, while determining the factor structure, the lower breakpoint was accepted as .40. As a result of the rotating process, it was determined that there was no substance overlapping the factors and they carried values far above the lower cutting point. Therefore, the draft scale consisting of 17 items was preserved before the Confirmatory Factor Analysis. The factor consisting of items 1-2-3-4 on the scale was called Sport Discipline Efficacy, the factor consisting of items 5-6-7-8 was called Psychological Efficacy, the factor consisting of items 9-10-11-12 was called Professional Thought Efficacy and finally the factor consisting of items 1314-15-16-17 was called Personality Efficacy (Table 5).

Considering the modification indices suggested in the confirmatory factor analysis, the 13 th item in the trial scale was removed from the scale. In addition, 16-item 4-dimensional model was confirmed by applying modifications between the 1 st and the 2 nd items, the 14 th and the 15th items, which are within the same factor (Table 6, Figure 2). 
It is sufficient to evaluate $\chi 2$ / $\mathrm{df}$ rate, RMR or RMS, GFI, AGFI, CFI, NFI, RMSEA compliance indices widely in CFA [21, 29]. While evaluating the fit indices in CFA, it was stated that $<2$ values can be accepted as perfect fit and $<3$ values can be accepted as acceptable fit for $\chi^{2} / \mathrm{df}$ ratio. Similarly, $>0.95$ is the perfect fit; $>0.90$ is the acceptable fit value for GFI, CFI, NFI, RFI, IFI and AGFI indices [30, 31]. The 0.05 value should be considered as perfect fit and 0.08 value as acceptable fit value for other fit indices RMSEA and RMR $[32,33]$. However, there are also researchers [34, 35] who state that GFI > 0.85 and AGFI $>0.80$ fit index values can be considered as acceptable levels for the evaluation of the fit index. In this study, $\chi^{2} / \mathrm{df}$ rate, NFI, NNFI, CFI, IFI, RFI, AGFI, GFI, RMSEA and RMR fit indices were evaluated for CFA.

CFA calculated the critical $n$ value as 156.41 for this research. This finding reveals that the sample size of 325 people in the study is sufficient. When the fit indexes of the scale are evaluated, $\chi^{2} / \mathrm{df}(2.72<3)$ is good fit, NFI $(0.95 \geq 0.95)$ is perfect fit, NNFI $(0.96>$ $0.95)$ is perfect fit, CFI $(0.97>0.95)$, IFI $(0.97>0.95)$, RFI $(0.97>0.95)$ indices were found to be perfect fit. However, AGFI (0.87 > 0.85), GFI $(0.91>0.90)$, RMSEA $(0.073<$ $0.08)$, RMR $(0.054<0.08)$ indices were found to be good fit.

Cronbach's Alpha Reliability Coefficient was used to determine the internal consistency between the total of the trial scale and its factors. The reliability coefficient is shown with values between 0 and 1 , and as this value approaches 1 , the reliability increases [36]. However, it is stated that a value of at least 0.70 is sufficient for the calculated coefficient [37]. In this study, Cronbach's alpha internal consistency coefficients were found to be .898 for the total scale, .841 for Sport Discipline Efficacy Dimension, .756 for Psychological Efficacy Dimension, .752 for Professional Thought Efficacy Dimension and .760 for Personality Efficacy Dimension. Similarly, it was determined that the scale dimensions had a positive correlation with each other and with the total scale. The obtained internal consistency coefficients and correlation values showed clearly that the scale and its sub-dimensions were consistent and had a distinctive feature. In this respect, the scale is compatible with the literature. This results shows that the scale is strongly reliable.

\section{CONCLUSIONS}

As a result, a scale with psychometric properties that can measure athlete's self-efficacy which is compatible with the theoretical framework that has been developed. The developed Athlete Self-Efficacy Scale consists of 16 items and 4 sub-dimensions. Sport Discipline Efficacy (items 1-2-3-4), Psychological Efficacy (items 5-6-7-8), Professional Thought Efficacy (items 9-10-11-12) and Personality Efficacy (items 13-14-15-16) names are given to the sub-dimensions of the scale. The lowest score that can be obtained from the scale is 16 , and the highest score is 80 . Three levels were determined in order to evaluate the average scores and self-efficacy levels to be obtained from the scale. These are: 3.34-5.00 points is high athlete self-efficacy level, 1.67-3.33 points is moderate athlete self-efficacy level and 0.00-1.66 points is low athlete self-efficacy level. Finally, the Athlete Self-Efficacy Scale can be used to measure self-efficacy of Turkish athletes.

Validity and reliability studies of the Athlete Self-Efficacy Scale should be repeated specific to the sport discipline or in younger age groups. In addition, athlete's self-efficacy is a universal concept. In this respect, it is valid in other cultures, and adapting the scale to other languages and cultures is recommended. 


\section{REFERENCES}

[1] Guillen F, Sanchez R. Competitive anxiety in expert female athletes: sources and intensity of anxiety in national team and first division Spanish basketball players. Percept. Mot. Skills. 2009;109(2):407-19. https://doi.org/10.2466/ pms.109.2.407-419

[2] Jarvis, M. Sport psychology: A student's handbook. London: Routledge; 2006, 18-22. https://doi.org/10.4324/9780203965214

[3] Martens R, Vealey RS, Burton D. Competitive anxiety in sport. Champaign, IL: Human Kinetics Publishers; 1990, 34-36.

[4] Bandura A. On the functional properties of perceived self-efficacy revisited. J Management. 2012; 38(1): 9-44. https://doi.org/10.1177/0149206311410606

[5] Bandura, A. Self-efficacy: The exercise of control. New York: W. H. Freeman; 1997, 12-20.

[6] Tong Y, Shanggui S. A Study on general self-efficacy and subjective well-being of low SES college students in a Chinese university. College Students Journal. 2004; 38 (4), 637-642. [Available at https://www.questia.com/library/ journal/1G1-126386904/a-study-on-general-self-efficacy-and-subjective-well-being] [Accessed on 17 March, 2020]

[7] Feltz DL, Weiss MR. Developing self-efficacy through sport. J Phys Educ Recr Dance. 1982;53(3):24-36. https://doi. org/10.1080/07303084.1982.10629341

[8] Feltz DL, Short SE, Sullivan P J. Self-efficacy in sport. Champaign, IL: Human Kinetics; 2008, 21-57.

[9] Myers ND, Feltz DL, Chase MA, Reckase MD, Hancock GR. The coaching efficacy scale II-High school teams. Educ Psychol Measur. 2008;68(6):1059-1076. https://doi.org/10.1177/0013164408318773

[10] Bandura A. Exercise of personal and collective efficacy in changing societies, In A. Bandura (Ed), Self-efficacy in changing societies. New York: Cambridege University; 1995, 32-56. https://doi.org/10.1017/CBO9780511527692

[11] Koçak ÇV, Güven Ö. The validity and reliability study of professional self-efficacy scale for volleyball coach. Spormetre the Journal of Physical Education and Sport Sciences. 2018;16(2):162-177. https://doi.org/10.1501/Sporm_0000000363

[12] Pajares F. Current Directions in Self-efficacy research. I:n M. Maehr \& P. R. Pintrich (Eds.). Advances in motivation and achievement. 2007; 10, 1-49. [Available at https://www.dynaread.com/current-directions-in-self-efficacy-research] [Accessed on 17 March, 2020]

[13] Bandura A. Guide for constructing self-efficacy scales. Self-efficacy beliefs of adolescents. Connecticut: Information Age Publishing; 2006, 307-337.

[14] Pajares F. Self-efficacy beliefs in academic settings. Rev Educ Res. 1996;66(4):543-576. https://doi. org/10.3102/00346543066004543

[15] Resnick B, Jenkins LS. Testing the reliability and validity of the self-efficacy for exercise scale. NursingRes. 2000;49(3):154-159. https://doi.org/10.1097/00006199-200005000-00007

[16] Resnick B, Zimmerman SI, Orwig D, Furstenberg AL, Magaziner J. Outcome expectations for exercise scale: Utility and psychometrics. The Journals of Gerontology Series B: Psychological Sciences and Social Sciences. 2000;55(6): S352-S356. https://doi.org/10.1093/geronb/55.6.S352

[17] Llewellyn DJ, Sanchez X, Asghar A, Jones G. Self-efficacy, risk taking and performance in rock climbing. Personality and Individual Differences. 2008;45:75-81. https://doi.org/10.1016/j.paid.2008.03.001

[18] Aras D, Koçak F, Çetinkaya G. The validity and reliability of the climbing self-efficacy scale-Turkish form. Spormetre the Journal of Physical Education and Sport Sciences. 2019;17(1):113-124. https://doi.org/10.33689/spormetre.492619

[19] Feltz DL, Chase MA, Moritz SE, Sullivan PJ. A conceptual model of coaching efficacy: Preliminary investigation and instrument development. J Education Psychol. 1999;91:765-776. https://doi.org/10.1037/0022-0663.91.4.765

[20] Myers ND, Feltz DL, Guillén F, Dithurbide L. Development of, and initial validity evidence for, the Referee SelfEfficacy Scale: A multistudy report. J Sport Exerc Psychol. 2012;34(6):737-765. https://doi.org/10.1123/jsep.34.6.737

[21] Çokluk Ö, Şekercioğlu G, Büyüköztürk Ş. Multivariate statistics for social sciences. SPSS and LISREL applications. Ankara: Pegem A Yayıncillk. 2010, 62-76.

[22] Cohen LM, Manion L. Research methods in education. New York: Routledge. 1998, 82-84.

[23] Ercan İ, Kan İ. Reliability and validity in the scales. Journal of Uludağ University Medical Faculty. 2004; 30 (3):21116. [Available at https://pdfs.semanticscholar.org/1566/cf670552eaee9872a121303153125136cc97.pdf] [Accessed on 17 March, 2020]

[24] Karasar N. Scientific research method, 20th. Ed., Nobel Yayın Dağıtım, Ankara. 2009, 56-70. Turkish.

[25] Polit DF, Beck CT. The content validity index: are you sure you know what's being reported? Critique and recommendations. Res Nurs Health. 2006;29(5):489-497. https://doi.org/10.1002/nur.20147

[26] Büyüköztürk S. Data analysis handbook for social sciences - statistics, research pattern SPSS applications and interpretation. 13. Ed., Ankara: Pegem Akademi; 2011, 124.

[27] Tezbaşaran A. Likert type scale development guide. Ankara: Türk Psikologlar Derneği Yayınlarl; 1997, 56-66.

[28] Tavşancll E. Measuring Attitudes and data analysis with SPSS. Ankara: Nobel Yayın Dağıtım; 2006, 43-48.

[29] Yllmaz V, Çelik HE. Structural equation modeling with LISREL- I. Ankara: Pegem Akademi; 2009, 12-56.

[30] Bentler PM. Multivariate analysis with latent variables: Causal modeling. Ann Rev Psychol. 1980;31:419-456. https:// doi.org/10.1146/annurev.ps.31.020180.002223

[31] Marsh HW, Hau KT, Artelt C, Baumert J, Peschar JL. OECD’s brief self-report measure of educational psychology's most useful affective constructs: cross-cultural, psychometric comparisons across 25 countries. Int J Testing. 2006;6(4):311360. https://doi.org/10.1207/s15327574ijt0604_1

[32] Byrne BM, Campbell TL. Cross-cultural comparisons and the presumption of equivalent measurement and theoretical structure: A look beneath the surface. J Cross-Cult Psychol. 1999;30:555-574. https://doi. org/10.1177/0022022199030005001

[33] Browne MW, Cudeck R. Alternative ways of assessing model fit. In K. A. Bollen \& J. S. Long (Eds.), Testing Structural Equation Models. Newbury Park, CA: Sage; 1993, 136-162. 
[34] Marsh HW, Balla J. Goodness of fit in confirmatory factor analysis: The effects of sample size and model parsimony. Quality and Quantity: International Journal of Methodology. 1989;28:185-217. https://doi.org/10.1007/BF01102761

[35] [35] Frias CM, Dixon RA. Confirmatory factor structure and measurement in variance of the memory compensation questionnaire. Psychological Assessment. 2005; 17(2): 168-178. https://doi.org/10.1037/1040-3590.17.2.168

[36] Ural A, Kılıç İ. Scientific research process and data analysis with SPSS. Ankara: Detay. 2006, 16-66.

[37] Karakoç FY, Dönmez L. Basic principles of scale development. Tıp Eğitimi Dünyası. 2014;13(40):39-49. https://doi. $\operatorname{org} / 10.25282 /$ ted.228738

\section{APPENDIX}

Sporcu Öz Yeterlik Ölçeği Türkçe Formu (Athlete Self Efficacy Scale (ASES) Turkish Form)

\begin{tabular}{|c|c|c|c|c|c|c|}
\hline \multirow[t]{2}{*}{ Boyutlar } & \multirow[t]{2}{*}{$\begin{array}{l}\text { Sporcu öz yeterliklerinize ilişkin inanç düzeyinizi } \\
\text { aşağıdaki ifadeler doğrultusunda işaretleyiniz. }\end{array}$} & 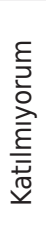 & 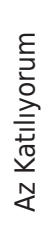 & 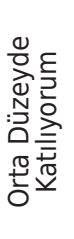 & 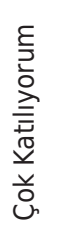 & 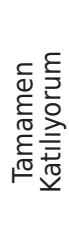 \\
\hline & & 1 & 2 & 3 & 4 & 5 \\
\hline \multirow{4}{*}{$\begin{array}{l}\text { Spor Dalı } \\
\text { Yeterliği }\end{array}$} & 1.Spor dalımın gerektirdiği fiziksel uygunluğa sahibim. & & & & & \\
\hline & 2.Spor dalımın gerektirdiği motor becerilere sahibim. & & & & & \\
\hline & 3.Spor dalımın gerektirdiği teknik becerilere sahibim. & & & & & \\
\hline & $\begin{array}{l}\text { 4.Karşılaşmada/yarışmada bireysel ve takım } \\
\text { taktiklerini başarıyla uygularım. }\end{array}$ & & & & & \\
\hline \multirow{4}{*}{$\begin{array}{l}\text { Psikolojik } \\
\text { Yeterlik }\end{array}$} & 5.Kendimi motive ederim. & & & & & \\
\hline & $\begin{array}{l}\text { 6. Takım arkadaşlarımın motive olmalarına yardımcı } \\
\text { olurum. }\end{array}$ & & & & & \\
\hline & 7.Üzerimde baskı oluşturan zorluklar ile başa çıkarım. & & & & & \\
\hline & 8.Duygularımı kontrol ederim. & & & & & \\
\hline \multirow{4}{*}{$\begin{array}{l}\text { Profesyonel } \\
\text { Düşünce } \\
\text { Yeterliği }\end{array}$} & 9.Sağlığımı korumaya özen gösteririm. & & & & & \\
\hline & $\begin{array}{l}\text { 10.Performans hedeflerime ulaşmak için özverili } \\
\text { çalışırım. }\end{array}$ & & & & & \\
\hline & $\begin{array}{l}\text { 11.Performansımı olumsuz etkilememesi için } \\
\text { yaşamımı düzenlerim. }\end{array}$ & & & & & \\
\hline & $\begin{array}{l}\text { 12.Performansımı korumak için sezon içinde ve sezon } \\
\text { dışında bireysel antrenman yaparım. }\end{array}$ & & & & & \\
\hline \multirow{4}{*}{ Kişilik Yeterliği } & $\begin{array}{l}\text { 13.Spor alanındaki paydaşlarımla etkili işbirliği } \\
\text { yaparak uyum içinde çalışırım. }\end{array}$ & & & & & \\
\hline & 14.Sportif erdeme (fair play) uygun davranırım. & & & & & \\
\hline & 15.Öz güvenim yüksektir. & & & & & \\
\hline & 16.Karşılaşmada/yarışmada sorumluluk alırım. & & & & & \\
\hline
\end{tabular}


The Athlete Self Efficacy Scale (ASES) English Form

\begin{tabular}{|c|c|c|c|c|c|c|}
\hline \multirow[t]{2}{*}{ Subdimension } & \multirow[t]{2}{*}{$\begin{array}{l}\text { Please mark your belief level for the athlete self- } \\
\text { efficacy accordance with the following statements }\end{array}$} & 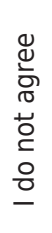 & 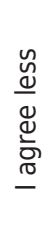 & 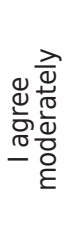 & 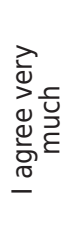 & 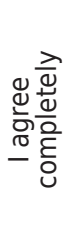 \\
\hline & & 1 & 2 & 3 & 4 & 5 \\
\hline \multirow{4}{*}{$\begin{array}{c}\text { Sport } \\
\text { Discipline } \\
\text { Efficacy }\end{array}$} & $\begin{array}{l}\text { 1. I have the physical fitness required for my sport } \\
\text { discipline }\end{array}$ & & & & & \\
\hline & $\begin{array}{l}\text { 2. I have the motor skills required for my sport } \\
\text { discipline. }\end{array}$ & & & & & \\
\hline & $\begin{array}{l}\text { 3. I have the technical skills required for my sport } \\
\text { discipline. }\end{array}$ & & & & & \\
\hline & $\begin{array}{l}\text { 4. I successfully apply the individual and team tactics } \\
\text { during the competition. }\end{array}$ & & & & & \\
\hline \multirow{4}{*}{$\begin{array}{l}\text { Psychological } \\
\text { Efficacy }\end{array}$} & 5. I motivate myself. & & & & & \\
\hline & 6. I help my teammates to be their motivation. & & & & & \\
\hline & 7. I cope with the difficulties that put pressure on me. & & & & & \\
\hline & 8. I control my emotions. & & & & & \\
\hline \multirow{4}{*}{$\begin{array}{l}\text { Professional } \\
\text { Thought } \\
\text { Efficacy }\end{array}$} & 9. I take care to protect my health. & & & & & \\
\hline & $\begin{array}{l}\text { 10. I work devotedly to achieve my performance } \\
\text { goals. }\end{array}$ & & & & & \\
\hline & $\begin{array}{l}\text { 11. I organize my life so that it does not affect my } \\
\text { performance negatively. }\end{array}$ & & & & & \\
\hline & $\begin{array}{l}\text { 12. In order to protect my performance, I train } \\
\text { individually in and out of season. }\end{array}$ & & & & & \\
\hline \multirow{4}{*}{$\begin{array}{l}\text { Personality } \\
\text { Efficacy }\end{array}$} & $\begin{array}{l}\text { 13. I effectively cooperate and work in cohesion with } \\
\text { my stakeholders in the field of sports. }\end{array}$ & & & & & \\
\hline & 14. I act in accordance with fair play. & & & & & \\
\hline & 15. I have high self-confidence. & & & & & \\
\hline & 16. I take responsibility during the competition. & & & & & \\
\hline
\end{tabular}

